\title{
Diversidad y sentido de las representaciones masculinas fálicas paleolíticas de Europa occidental
}

\author{
J. Angulo Cuesta*, M. García Díez** \\ *Servicio de Urología. Hospital Universitario de Getafe. Madrid. **Departamento de Geografia, Prehistoria y \\ Arqueología. Universidad del País Vasco. Vitoria.
}

Actas Urol Esp 2006; 30 (3): 254-267

\section{RESUMEN \\ DIVERSIDAD Y SENTIDO DE LAS REPRESENTACIONES MASCULINAS FÁLICAS PALEOLÍTICAS DE EUROPA OCCIDENTAL}

Las evidencias arqueológicas que permiten comprender cómo entendían la sexualidad nuestros ancestros del Paleolítico superior (38.000-8.500 a.C.) son escasas. Tradicionalmente se ha dado mucha importancia a la información etnográfica referida a la sexualidad y a las relaciones entre sexos que procede de comparaciones con pueblos primitivos actuales, valorándose más desde un punto de vista sociológico y antropológico que biológico.

$\mathrm{El}$ arte prehistórico, en su doble vertiente parietal y mobiliar, es un reflejo de los comportamientos de los grupos paleolíticos. El sentido de este texto se centra en inferir, a partir de las imágenes masculinas de carácter fálico, los tipos de representaciones y las actitudes sexuales del Paleolítico superior.

Prácticas de retracción del prepucio, algunos falos posiblemente circuncidados, actos copulativos, gestos de onanismo, instrumentos posiblemente empleados para la masturbación y otras escenas de indole sexual, algunas de ellas difíciles de interpretar, muestran que los comportamientos sexuales de las gentes del Paleolítico superior eran, desde un punto de vista biológico y fisiológico, similares a los nuestros.

Palabras clave: Representaciones masculinas fálicas. Comportamiento sexual. Arte parietal y mobiliar, Paleolítico superior. Prehistoria. Europa occidental.

\section{ABSTRACT \\ DIVERSITY AND MEANING OF MASCULINE PHALLIC PALAEOLITHIC IMAGES IN WESTERN EUROPE}

The archaeological record necessary to understand the sexual behaviour of our ancestors from Upper Palaeolithic (38.000-8.500 B.C.) is limited. Traditionally the ethnographic information about sexuality and the relations between sexes derived from comparitions with current primitive human groups have been considered very important, although they have been evaluated more from a social and anthropological rather than biological perspective.

Ice age art art, both rock and portable, is a reflection of the behaviour of palaeolithic human groups. The purpose of this text focuses on understanding the types of representations and sexual attitudes during the Upper Palaeolithic, as reflected from masculine images of phallic character.

Practices of foreskin retraction, some phalli possibly circumcised, copulative acts, expressions of masturbation, instruments that have been likely been used for masturbation and other sexual scenes, some of which are difficult to interpretate, show that the sexual behaviour of the human groups of the Upper Palaeolithic were similar to ours, both from a biological and physiological viewpoint.

Keywords: Masculine phallic images. Sexual behaviour. Rock and portable art. Upper Palaeolithic. Prehistory. Western Europe. 
$\mathrm{A}^{\mathrm{h}}$ hondar en los orígenes del comportamiento sexual no es sencillo. Si hoy no tenemos un conocimiento preciso del comportamiento sexual de nuestros congéneres debido a condicionantes culturales y religiosos y a nuestros propios prejuicios, más limitados estaremos a la hora de conocer las actitudes sexuales de sociedades pasadas que no tuvieron un sistema de comunicación como la escritura. La reconstrucción de épocas prehistóricas es problemática. Huesos, piedras, pinturas y colgantes son algunos de los documentos de los que hoy se dispone para alcanzar un conocimiento del comportamiento humano en los albores de la Humanidad.

Desde el primer homínido hasta nosotros, el Homo sapiens, las actitudes sexuales a bien seguro han variado. Simplificando se podría decir que se pasó de un comportamiento animal a otro propiamente humano, en el que además de lo reproductivo entrarian en juego otros factores: erotismo, placer, belleza, amor, posesión, sensualidad... Desde el proceso fisiológico animal que supone el cortejo de apareamiento y el ritual copulativo hasta las complicadas manifestaciones de la esfera sexual humana que constituyen el amor, entendido como proceso físico y psicológico, ha sido necesario todo un proceso evolutivo que se podría denominar la Hominización sexual. Nunca sabremos del todo en qué momento tuvo lugar esa esencia, cuándo la llamada sexual se convirtió en erotismo y el acto reproductivo se transformó en un fenómeno sociológico.

Existe una herramienta básica para comprender los mecanismos del comportamiento humano paleolítico, tanto en lo que se refiere al aspecto exterior como a la conducta. Las evidencias que mayor información presentan a este respecto son los grabados, pinturas y dibujos del Paleolítico superior que se han localizado en cuevas, abrigos $\mathrm{y}$ rocas al aire libre ${ }^{1-4}$.

\section{CONTEXTO CULTURAL EN EL QUE SE REALIZAN LAS IMÁGENES FÁLICAS}

El Homo sapiens se conoce en África hace unos 200.000 años $^{5-7}$. Parece que salió de dicho continente hace unos 100.000 años, aunque su expansión más notable se produjo hace unos 40.000 años cuando colonizó toda Europa. A esta etapa crono-cultural se conoce como Paleolítico superior (38.000 a 8.500 años a.C. $)^{8-10}$.
Se considera que el comportamiento moderno está presente en Homo neanthertalensis, pero su generalización en términos sociales se produce con Homo sapiens. Los elementos que se definen como modernos son el desarrollo de una tecnología de talla laminar, el trabajo intensivo de materias orgánicas, la generalización de los adornos corporales, del sentimiento artístico y de los enterramientos, la estructuración del hábitat, el aprovechamiento planificado de los recursos y la intensificación de las relaciones a larga distancia.

En cuanto al trabajo de la piedra se configuran soportes para extraer láminas estrechas $\mathrm{y}$ alargadas, consiguiendo un mayor aprovechamiento de la materia prima y unos filos cortantes y largos. Se produce una diversificación y estandarización, apareciendo una variedad de tipos que se adecuan a trabajos concretos como cortar carne, machacar huesos o trabajar la madera. Buriles, raederas, raspadores, denticulados, muescas, puntas y cuchillos forman parte del equipamiento. El trabajo del hueso y asta es una de las actividades más importantes. Aparecen nuevas técnicas de trabajo como el pulido y la abrasión. Las azagayas, utilizadas como armas arrojadizas, los arpones y anzuelos, y otros instrumentos como varillas, punzones, espátulas, agujas, etc. completan el stock utilizado para la caza, la pesca y el trabajo de la piel.

Los instrumentos han servido para estructurar los aproximadamente 30.000 años que dura el Paleolítico superior europeo. El tramo inicial (38.000-18.000 a.C.) integra los tecnocomplejos Chatelperroniense, Auriñaciense y Gravetiense. El tramo medio dura unos 2.000 años y se corresponde con el Solutrense. Durante el tramo final, que alcanza hasta los 8.500 años a.C, se desarrolla el Magdaleniense, caracterizado por una diversificación acusada de tipos industriales y una importante actividad artística y simbólica. Los estudios ponen de manifiesto realidades culturales de carácter regional y supraregional.

El adorno corporal jugó un papel social importante. Conchas y dientes de animales perforados aparecen por toda Europa. Más allá de lo puramente decorativo estos soportes se utilizaron como elementos de distinción y diferenciación social. También se generalizó el sentimiento relacionado con la muerte, como demuestran los 
enterramientos individuales y colectivos conocidos. Las inhumaciones son sencillas, depositando el cuerpo boca arriba o flexionado sobre una fosa normalmente no acondicionada. Lo más novedoso es la generalización del "ritual funerario", que emplea adornos, instrumentos líticos y óseos, y ocre.

Se asiste a la estructuración del espacio de hábitat, pero lo más destacado son las construcciones de cabañas que se han venido descubriendo en aquellos lugares donde la geología no disponía cuevas o abrigos donde refugiarse.

La base alimenticia se componía de recursos cárnicos animales, fluviales $\mathrm{y}$ vegetales. Los recursos silvestres (como frutos y raíces) hubieron de tener importancia. Los fluviales están documentados por restos de peces e instrumentos como arpones y anzuelos. La carne obtenida de grandes herbívoros (como cabras, ciervos, caballos y bisontes) suponía un aporte básico para la alimentación. La caza indiscriminada y oportunista que se venía practicando se especializó y diversificó a partir de los inicios del Magdaleniense, seleccionándose las piezas dependiendo de la edad y sexo.

A pesar de que los grupos cazadores-recolectores-pescadores del Paleolítico superior siguieron siendo nómadas, se observa cierto grado de intensificación de las ocupaciones y una reducción de los movimientos migratorios. Parece que los asentamientos son de media y larga duración y con carácter estacional, dependientes de la cantidad de recursos alimenticios. También se documentan intercambios y movilidad a larga distancia. En algunos yacimientos se han recogido sílex que proceden de varios kilómetros de distancia. También se han recuperado colgantes que presentan similitudes con otros de yacimientos que distan 100, 200 o incluso más de $500 \mathrm{Km}$. Todo indica que existieron relaciones entre grupos muy distantes que compartian una serie de rasgos culturales comunes. Algunos investigadores han querido ver en estas similitudes sistemas de intercambio.

Una de las creaciones más destacadas del Paleolítico superior es el desarrollo de un imaginario simbólico compuesto por representaciones artísticas que encierran estética y necesidad de transmitir conceptos ${ }^{11-14}$. Se distingue entre obras que se sitúan en una pared de cueva, abrigo o roca al aire libre (arte parietal o rupestre) y las que pueden trasladarse de un sitio a otro (arte mobiliar). Este último se clasifica según la materia prima (orgánica o inorgánica) y el tipo de soporte (de uso precario o prolongado). También se asocian a lo mobiliar figuras esculpidas e innumerables conjuntos de placas de piedra decoradas.

El arte paleolítico presenta una gama de recursos técnicos limitada. En lo parietal destacan el dibujo, la pintura y el grabado, mientras que en lo mobiliar el grabado es el recurso técnico preferente, aunque también se ha practicado el bajorrelieve parietal y la escultura.

La organización temática distingue un grupo figurativo de formas animales y humanas (las referencias al paisaje están prácticamente ausentes) y otro abstracto que integra motivos lineales y geométricos denominados ideomorfos o signos. Bajo este último término se incluye una amplia variedad de estructuras lineales y geométricas, entre las que destacan: claviformes (en forma de clava), escutiformes (de escudo), laciformes (de lazo), tectiformes (de construcción tipo cabaña), vulvas (de orificio sexual femenino), meandriformes (de meandro), arboriformes (de árbol), etc. A pesar de la diversidad de fauna que debieron conocer los paleolíticos, predominan los animales de talla grande: caballo, bisonte, uro -el antiguo toro o vaca-, ciervo, cabra, mamut, reno, oso, megácero, león, rinoceronte, cánido y antílope saiga. También se han representado, aunque en escasas ocasiones, peces, animales acuáticos (focas y ballenas), aves (anátidas, rapaces y pingüinos), reptiles e insectos. Además se documentan escasos ejemplos de figuras que comparten caracteres de al menos dos animales diferentes. La representación humana es minoritaria y puede estar representada por formas femeninas, masculinas, indeterminables y mixtas (combinación de caracteres humanos y animales). Las femeninas son las más representadas. Casi siempre se presentan desnudas, sin indumentaria o adorno corporal, y se identifican por los rasgos faciales o por el carácter vertical del cuerpo.

Desde planteamientos etnográficos, neuropsicológicos, semiológicos y estructuralistas se han planteado explicaciones acerca del significa- 
do de este arte. Esta variabilidad interpretativa pone de relieve las dificultades de utilizar un solo enfoque para descifrar el porqué y el para qué del arte paleolítico, más aún cuando se puede aceptar que un mismo significante (un motivo) puede tener varios significados, poniéndose de relieve la especificidad, individualidad e idiosincrasia de los autores y de los grupos humanos. Lo que sí parece evidente para cualquier conjunto artístico es que la representación gráfica responde a un esquema previo, consecuencia de un proceso de reflexión donde se decidió qué pintar, donde pintar y cómo disponer las figuras, líneas, puntos y geometrías. Además el grafismo posee un valor estético, porque a través de la forma se consigue también alterar el sentido y sentimiento del observador.

\section{TIPOLOGÍA Y CARACTERES DE LAS REPRESENTACIONES FÁLICAS}

Son pocas las figuras que explícitamente muestran atributos sexuales claramente masculinos en el imaginario paleolítico conocido a día de hoy en Europa Occidental ${ }^{4,15,16}$. Desde un punto de vista descriptivo se pueden organizar en imágenes fálicas abreviadas, estatuillas exentas, e imágenes completas de lo masculino.

\section{Imágenes fálicas abreviadas}

Las representaciones abreviadas de carácter fálico aparecen bajo tres concepciones diferentes: soportes escultóricos o bajorrelieves, grabados y soportes muebles de configuración fálica. Todas ellas tienen en común el que plantean la representación fálica de manera exclusiva y por ello con tendencia a la simplificación del carácter masculino.

Son muy pocas las imágenes escultóricas o de relieves. De hecho sólo se tiene conocimiento claro a día de hoy de tres ejemplos evidentes y bien documentados, todos de cronología auriñaco-gravetiense (en torno a 38.000-18.000 años a.C.). En el yacimiento de Laussel se descubrió un fragmento de glande esculpido en una roca de 5 centímetros de tamaño en el que se aprecia claramente el meato uretral y el rebaje que corresponde a la fosita navicular de la uretra. Otro ejemplo es el bajorrelieve con forma fálica de tendencia apuntada en el extremo distal y roma en el proximal hallado en el sitio de Laugerie-Haute (Fig. 1); junto a él se descubrió otro bloque de piedra con un relieve similar pero abierto en ambos extremos, por lo que se reconoce como forma vulvar. Por último en el abrigo Castanet, en Sergeac, se descubrió otro bloque con un relieve de carácter fálico, próximo a varios bloques con múltiples formas vulvares.

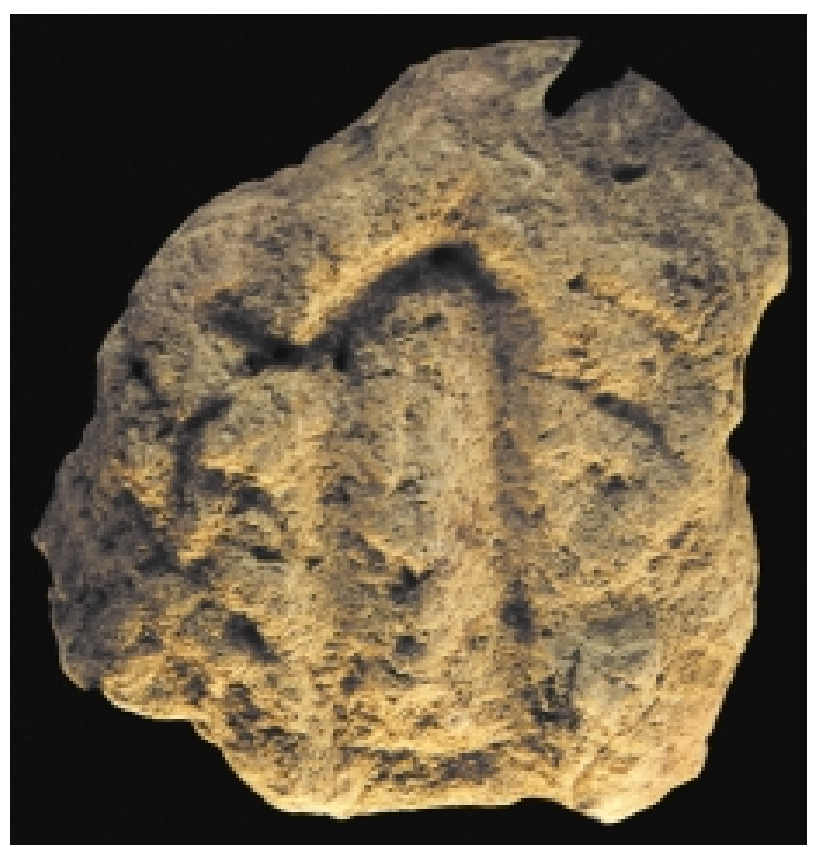

FIGURA 1. Bloque de piedra con representación de falo del abrigo de Laugerie-Haute.

También son muy escasos los ejemplos de sexos masculinos grabados o pintados. Uno de los más destacados es el pene con glande existente en la pared de la cueva de Fronsac. Otros ejemplares como los de Bédeilhac, Les Combarelles o Chufín aparecen también en cuevas. En relación con este grupo se pudieran considerar los signos que Leroi-Gourhan ${ }^{12}$ interpretó como masculinos (líneas simples, puntos componiendo líneas y líneas con ramificaciones laterales, entre otros). Si esta consideración fuera correcta, serian innumerables las referencias a lo masculino en el arte paleolítico, pero creemos que dicha valoración de modo alguno puede ser sostenida con carácter general.

Los soportes muebles con morfología de pene son la categoría fálica más numerosa y suelen ir acompañados de grabados de animales o signos. 
Destacan el conjunto de utensilios, generalmente bastones de mando, con forma fálica en al menos uno de sus extremos. Existen ejemplos de ello tanto en los yacimientos peninsulares de El Pendo, Valle y Cueto de la Mina como en los sitios franceses de Bruniquel, Blanchard, Gorge d`Enfer, La Madeleine o Farincourt (Fig. 2), entre otros. Las piezas de Gorge d'Enfer y Bruniquel son sin duda las más llamativas. En la primera de las cuevas, situada en Dordoña, se recuperó un fragmento de bastón bifurcado en el extremo proximal; cada uno de estos apéndices representa la forma de un pene con glande y meato. En Bruniquel, en Tarn-et-Garonne, dos bastones de mando decorados con signos y peces presentan el extremo distal a modo de pene, también con la indicación del glande y del meato.

Por último, e introduciendo un cierto grado de presunción, pudieran interpretarse algunas for-

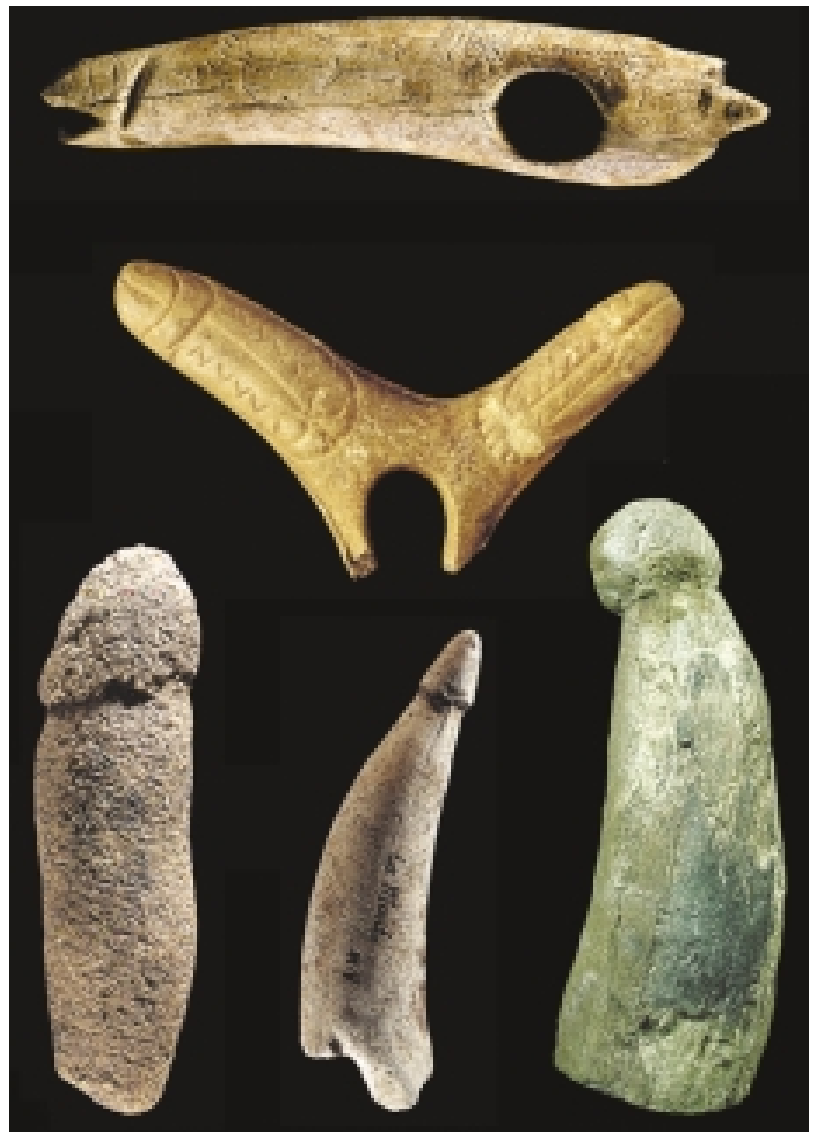

FIGURA 2. Representaciones fálicas sobre soporte mueble: El Pendo (foto P. Saura), Gorges d'Enfer, La Madeleine, Blanchard y Castanet. maciones calcáreas (tipo estalagmitas y estalactitas) a modo de sugerencias fálicas, que si bien $a$ priori nos pueden parecer evidentes son difíciles de certificar. En ocasiones la presencia de un recubrimiento intencional de ocre sobre estas formas naturales pudiera apoyar esta hipótesis.

\section{Estatuillas exentas}

El grupo de estatuillas exentas es el que más refleja la escasez de figuras masculinas en relación a las femeninas. Si las llamadas venus son numerosas y se reparten por la mayor parte de la geografía mundial, las estatuillas masculinas aparecen aisladas y sin continuidad en su repartición espacial.

Una de las más llamativas se localizó en el yacimiento francés de Laussel. En el mismo contexto estratigráfico y cultural que la Dama del cuerno se recuperó una pequeña figura, llamada el Príapo, de poco más de 35 centímetros de alto y 11 de ancho, realizada sobre caliza (Fig. 3).

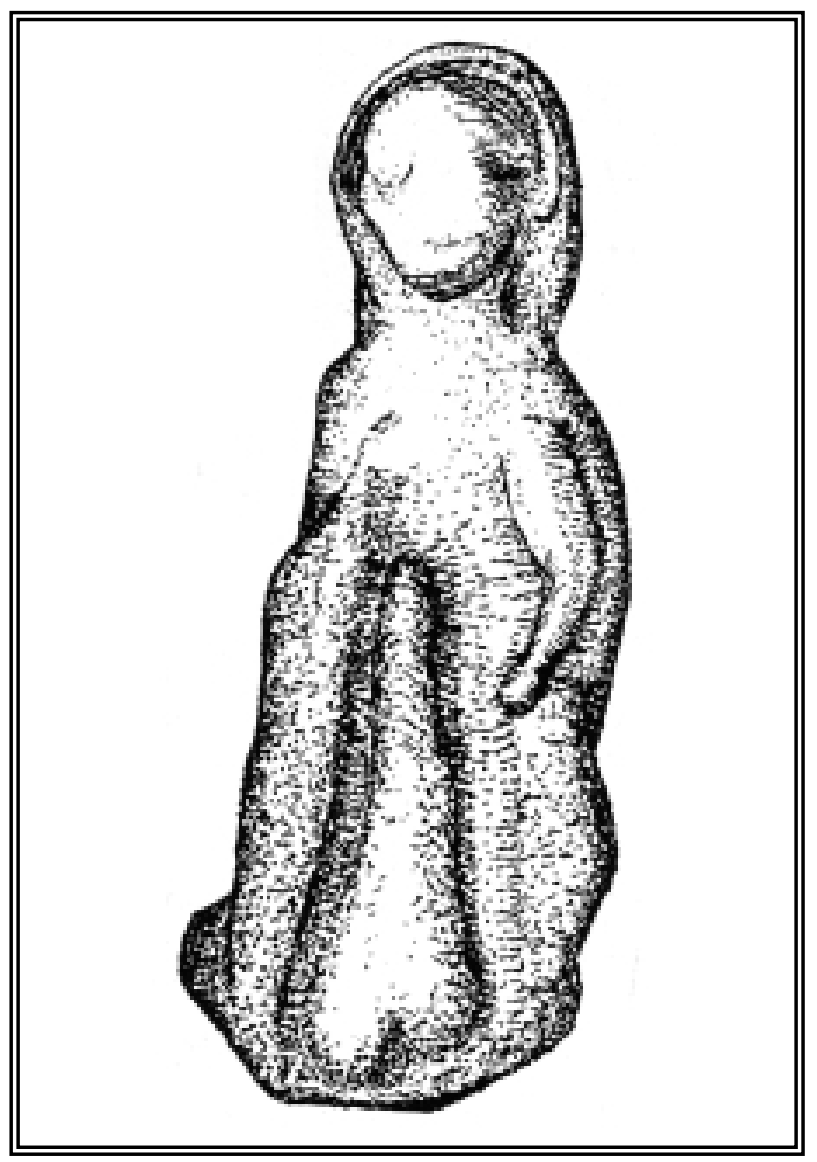

FIGURA 3. Escultura conocida como El Priapo de Laussel (calco J. P. Duhard). 
La escultura presenta una verga apuntada de dimensiones exageradas y una bolsa escrotal con los dos testículos en asimetría. La colocación de la verga no es anatómicamente correcta debido a que el sexo parece arrancar de la base de las extremidades inferiores. Las enormes dimensiones del órgano sexual y su incoherente posición anatómica llevan a centrar toda la atención del observador en el pene.

También en Francia, y en un contexto asociado a figuras tipo venus, Brassempouy ha entregado una figura humana de género bastante discutido pero que finalmente ha sido descrita como masculina con un pequeño pene redondeado y un sacro escrotal rechoncho. También sin mostrar estado de erección se encontró una parcial representación humana de la que destaca un pequeño y saliente pene en el yacimiento checo de Brno II; pero lo más llamativo no es sólo la figura sino su contexto, ya que apareció asociada a un esqueleto masculino rodeado de restos de fauna, ocre, discos y más de 600 piezas de collar.

Ahora bien, el reducido número de efectivos no deja ver una interpretación clara de este tipo de figuras. La imagen más expresiva es el Príapo de Laussel. Consideramos que su carácter erecto y el tamaño del pene no deben ser necesariamente interpretados desde el punto de vista clínico, sino probablemente desde un simbolismo manifiesto de la masculinidad y, porqué no, de la fecundidad si se asume la inferencia consciente del papel masculino en la reproducción, en relación directa con la expresividad manifiesta del mismo carácter en una gran parte de las estatuillas femeninas. Por otro lado, el Príapo bien pudiera representar un caso de priapismo que -de haberse producido en época paleolítica- seguramente hubiese impresionado enormemente a quienes lo vieron, pudiendo haber generado incluso un mito capaz de incorporarse al subconsciente colectivo.
Pinturas y grabados: imágenes completas de lo masculino

Son más numerosas, y casi siempre de cronología magdaleniense, las figuras pintadas o grabadas que se encuentran en soportes muebles y parietales (Figs. 4 y 5), y que en muchas ocasiones hacen referencia explícita al sexo masculino. Destacan las que pueden observarse en yacimientos como Les Combarelles, Saint-Cirq, Altamira, Hornos de la Peña, Ribeira de Piscos, Le Portel, La Madeleine, Addaura, Isturitz y Mas d'Azil. Asímismo, en el sitio francés de La Marche, en Vienne, se recuperó un importante lote de placas grabadas con figuras masculinas, algunas de las cuales pueden incluirse en el apartado de retratos. En muchas de ellas la representación evidente del pene o de la barba, o de detalles anatómicos como los ojos, la boca, la nariz y las extremidades hacen de este conjunto unos de los principales documentos para conocer la fisonomía humana paleolítica.

Como se ha señalado, entre estos motivos masculinos son relativamente abundantes los que representan el sexo. Los encontramos desde Portugal hasta Italia, pasando por los dos países con mayor concentración de muestras artísticas paleolíticas, España y Francia. A pesar de que la mayor parte de las imágenes se centran en el trazado del pene, el escroto aparece en algunos

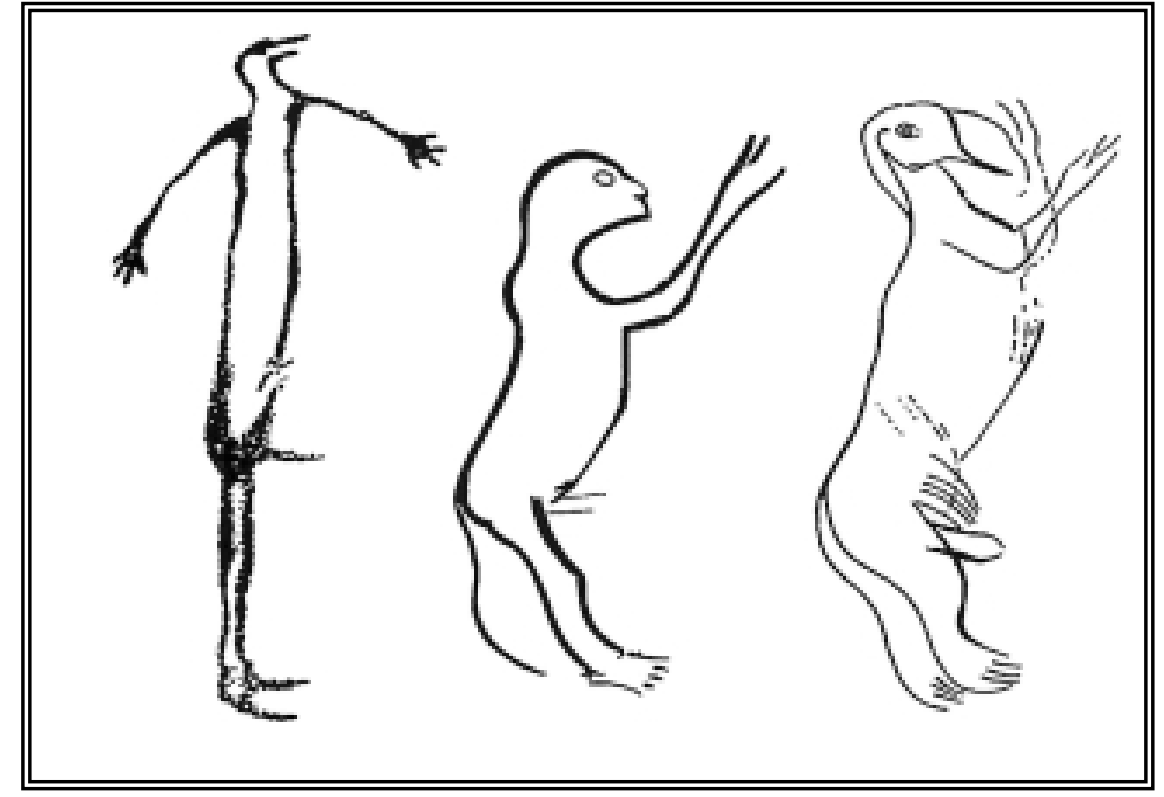

FIGURA 4. Antropomorfos itifálicos de Lascaux, Hornos de la Peña y Altamira (cal$\cos$ H. Breuil). 


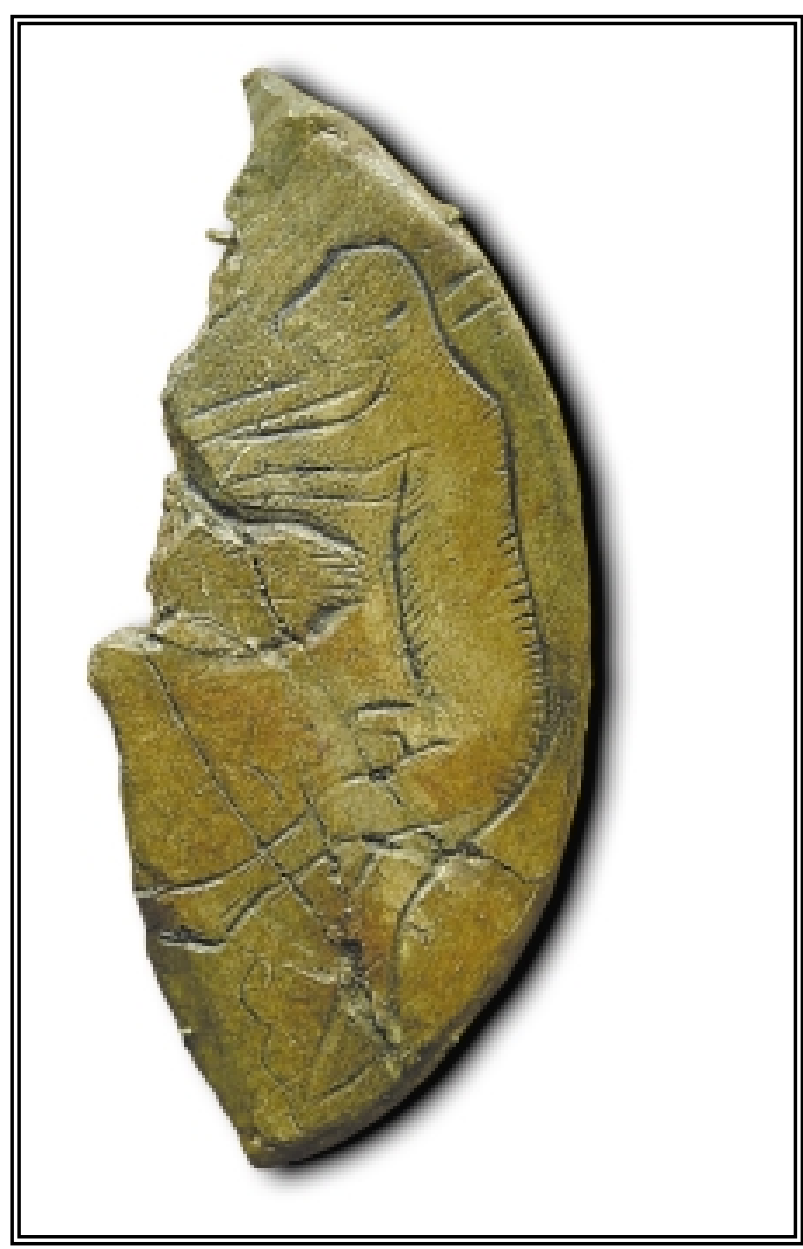

FIGURA 5. Antropomorfo itifálico sobre fragmento de rodete de Mas d'Azil.

ejemplares de Addaura, el hombre-bóvido de Gabillou, en la cópula del Abri Murat o en el enigmático hombre-ciervo o Dios de Trois-Frères, en el que se pone de manifiesto el proceso de animalización de la figura humana (Fig. 6); incluso se observa, aunque no tan claro, en el personaje de faz simiesca grabado sobre un canto en Mas d'Azil. En todos estos casos el escroto está diferenciado de la región hipogástrica y del pene, y se representa a modo de un pequeño saco o bolsa.

La morfología del pene puede analizarse también en relación a la presencia o ausencia del prepucio. Éste es un aspecto difícil de valorar, ya que las ligeras variaciones formales del extremo final del pene no tienen porqué estar necesariamente relacionadas con un realismo anatómico. La tipología que no muestra indicación del glande es la más numerosa: en algunas ocasiones la terminación es apuntada (en la llamada cópula de Murat, la escena del pozo de Lascaux, el sujeto 109 de Gabillou, Addaura, sujetos 34 y 39 de La Marche, Laugerie-Basse, Tuc d'Audoubert, Gourhan, el "pequeño bisonte" de Trois-Frères y Les Combarelles entre otros) y en otras redondeada (en Mas d'Azil, el hombre acéfalo de Pergouset, el "grotesco" de Lourdes, Altamira y Sous-Grand-Lac). El carácter netamente apuntado de algunos falos sugiere la existencia de fimosis severa. Por otro lado la referencia explícita al glande descubierto es poco frecuente, pero destaca en el llamado Dios de Trois-Frères, el sujeto 60 de Marche, Riberia de Piscos, el "pequeño brujo" de Lascaux, Enlène y Saint-Cirq. Algunos de estos ejemplares pudieran ser llevados más allá en la valoración, especulando a partir de ellos sobre la ausencia del prepucio, lo que aventuraría posibles prácticas de circuncisión paleolíticas o, al menos, una indiscutible cultura de retracción del prepucio. No obstante se puede asumir que la circuncisión no hubo de ser norma cultural, puesto que, como se ha dicho, son llamativas algunas representaciones de penes fimóticos. Además existen representaciones, como el mencionado pene grabado en la cueva de Fronsac, en las que a pesar de su carácter erecto se aprecia prepucio redundante.

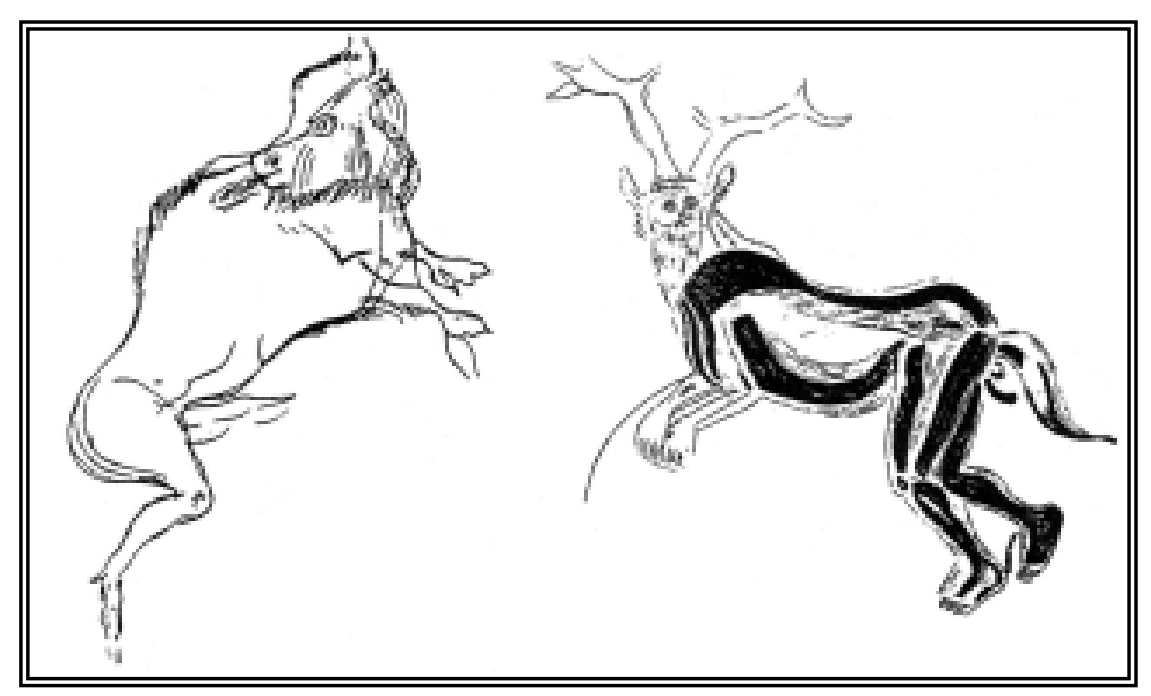

FIGURA 6. Representaciones hibridas itifálicas de Trois-Frères (calco C. Begöuen). 
$\mathrm{El}$ aprovechamiento de formaciones de calcita para figurar el sexo masculino es otro fenómeno gráfico muy raro. En la cueva francesa de Le Portel se documentan dos ejemplos. El artista dibujó en torno a dos salientes (en forma de pene) el contorno de sendas representaciones humanas, configurando dos figuras con la verga en estado erecto. Son evidencias de aprovechamiento de morfologías naturales y de interacción gráfica entre el artista y el soporte. Además esta representación peculiar implica que en la concepción del artista la forma fálica es determinante respecto a la forma humana.

De la mayor parte de estos grabados y pinturas destaca el carácter erecto del pene ${ }^{17}$. En la actualidad se conocen en torno a 25-30 casos de personajes itifálicos. La interpretación que se puede hacer de la predominante presencia de personajes erectos puede ser variada y a bien seguro que no será unívoca en la respuesta. La valoración más directa pudiera estar relacionada con la fertilidad: una consecuencia del estado erecto es la eyaculación y de ésta la inseminación y sucesivamente la potencial reproducción. También pudieran ser referidas como elementos de virilidad, e incluso algunos autores van más allá y entreven un símbolo de dominación masculina tanto respecto a sus semejantes como al entorno (lo que explicaría algunas asociaciones de humanos itifálicos con animales); pero ello no parece ser correcto ya que de ser así el número de estas imágenes debiera ser sensiblemente mayor.

\section{LAS REPRESENTACIONES MASCULINAS FÁLICAS Y LOS COMPORTAMIENTOS SEXUALES EN EL PALEOLÍTICO SUPERIOR}

Una de las características del arte paleolítico es la casi total ausencia de elementos expresivos y narrativos; ello es común tanto a los motivos animales como humanos ${ }^{18}$. Entre las representaciones animales se ha descrito una amplia variedad de actitudes, que incluyen escenas de lucha, de contacto urogenital $\mathrm{u}$ olisqueo de flujos, de preapareamiento y cópula, de cuidado maternofilial, de amamantamiento, de pasto y otras relacionadas con la vida cotidiana. Algunas figuras humanas se han trazado en asociación componiendo escenas de carácter reproductivo y se- xual, entendido como algo creativo. Los documentos artísticos que muestran referencias al sexo masculino en estado de erección y que permiten tener una apreciación de la actitud sexual son escasos. Estos se organizan de acuerdo a diferentes tipos de comportamiento que se enumeran a continuación.

\section{La cópula}

El coito es la culminación de un proceso en el que dos individuos se juntan sexualmente. Antes de alcanzar la penetración la pareja pasa por una fase de excitación, de tensión sexual, que en el hombre se manifiesta por la erección del pene y en la mujer por la apertura de los labios mayores y las secreciones vaginales. En este sentido, entre las imágenes de los grupos humanos del Paleolítico superior es posible reconocer actitudes relativas al coito.

En una de las paredes de la cueva francesa de Les Combarelles ${ }^{19}$ se grabó un panel que contiene tres motivos humanos datados en el Magdaleniense reciente-medio. Considerando las dos figuras de mayor tamaño (Fig. 7) se ha apuntado la posibilidad de estar frente a una escena de precópula. Situada en posición adelanta una figura de vientre ancho y caído y nalgas anchas tiende a posicionarse a cuatro patas; por detrás una figura claramente masculina, de dimensiones torácicas voluminosas, mostrando movimiento en las extremidades superiores y con el pene erecto $\mathrm{y}$ apuntado parece dirigirse hacia la anterior. La

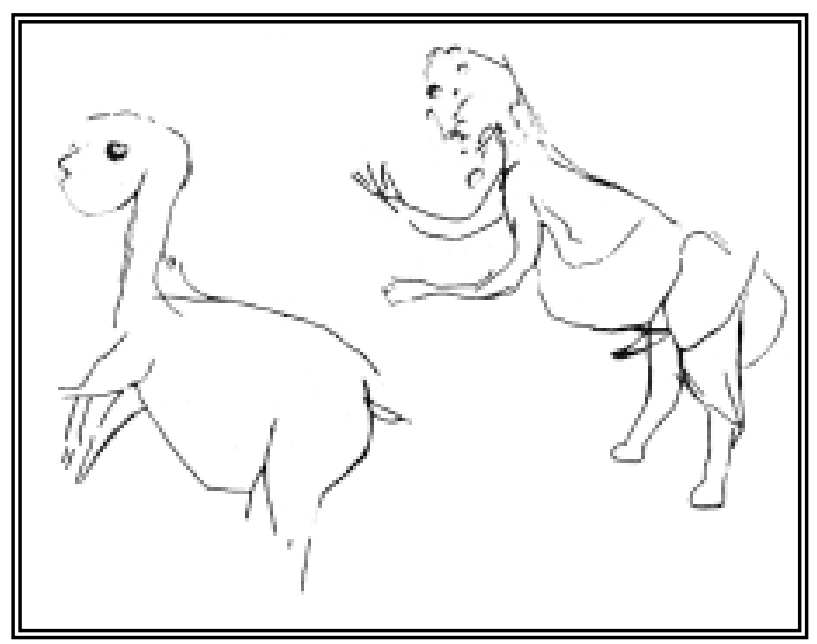

FIGURA 7. Escena de precoito de Les Combarelles (calco C. Barriere). 
morfología de la nalga y del vientre de la primera figura, que hacen considerar probable su determinación como femenina, la posición de ésta, el gesto y el carácter enhiesto del sexo del motivo masculino incitan a aceptar un momento previo a la penetración. El carácter erótico y sexual de la composición es evidente y la cópula parece ser la consecuencia más inmediata de la actitud de las figuras.

Además de la escena de Les Combarelles se reconocen otros ejemplos donde la penetración es un hecho consumado. Sobre la placa 39 del yacimiento de La Marche (Magdaleniense medio) ${ }^{20}$ se han vertido diferentes opiniones (Fig. 8B): desde que se trata de un oso y un humano enfrentados hasta la teoría del acto sexual. Esta segunda hipótesis, que consideramos pertinente, propone que se trata de dos humanos en posición frontalfrontal: el de la derecha presenta una gran verga erecta, de la que se intuye el glande, que se sitúa en correspondencia con la zona pubiana del otro. De este segundo no hay referencia alguna de su género, pero la posición enlazada de ambos personajes, el carácter erecto que muestra la verga del claramente masculino y la posición frontal de ambos hacen altamente probable el carácter femenino de la figura de la izquierda. De este modo representarian una escena de coito fronto-frontal, favoreciendo la penetración el carácter abrazado de los personajes. Se ha llegado incluso a proponer que la composición representa una postura coital tipo "el árbol floreciente", donde se consigue una penetración directa y profunda cuando el hombre recoge una de las piernas de la mujer en torno a un lado de la cadera ${ }^{21}$.

En la provincia de Guadalajara la cueva de Los Casares $^{22}$ presenta uno de los raros ejemplos de arte parietal con figuras antropomorfas trazadas con cierto carácter caricaturesco. Destaca un panel con grabados del que se han descrito dos figuras de mamut, una de ellas parcial, y dos antropomorfos. Uno de ellos con cabeza puntiaguda presenta una gran y ancha verga con glande que se dirige hacia el vientre de otra figura antropomorfa de vientre y glúteos abultados (Fig. 8A). Vinculan a ambas figuras las extremidades superiores que tienden a unirse. Se trata de una escena de cópula fronto-frontal que ha sido considerada como ejemplo de hierogamia o sexo sagrado ofrecido a una deidad animal ${ }^{23}$, en este caso el mamut.

Pero la postura frontal no es la única representada. Existe una plaqueta fragmentada procedente de Enlène que muestra una escena de coito. Se trata de una composición incompleta en la que dos figuras humanas se encuentran en posición de cópula fronto-dorsal. El personaje inferior se coloca "a cuatro patas" y tiene largo cabello que le cae sobre la cara. El otro personaje está arrodillado y realiza la penetración en la postura conocida como "la ofrenda"21. Es verdad que la ausencia de claros caracteres sexuales impide reconocer de manera explícita el género de cada personaje, pero la identificación hombremujer se puede establecer en base a una concepción tradicional de la relación sexual y a un sutil dimorfismo.

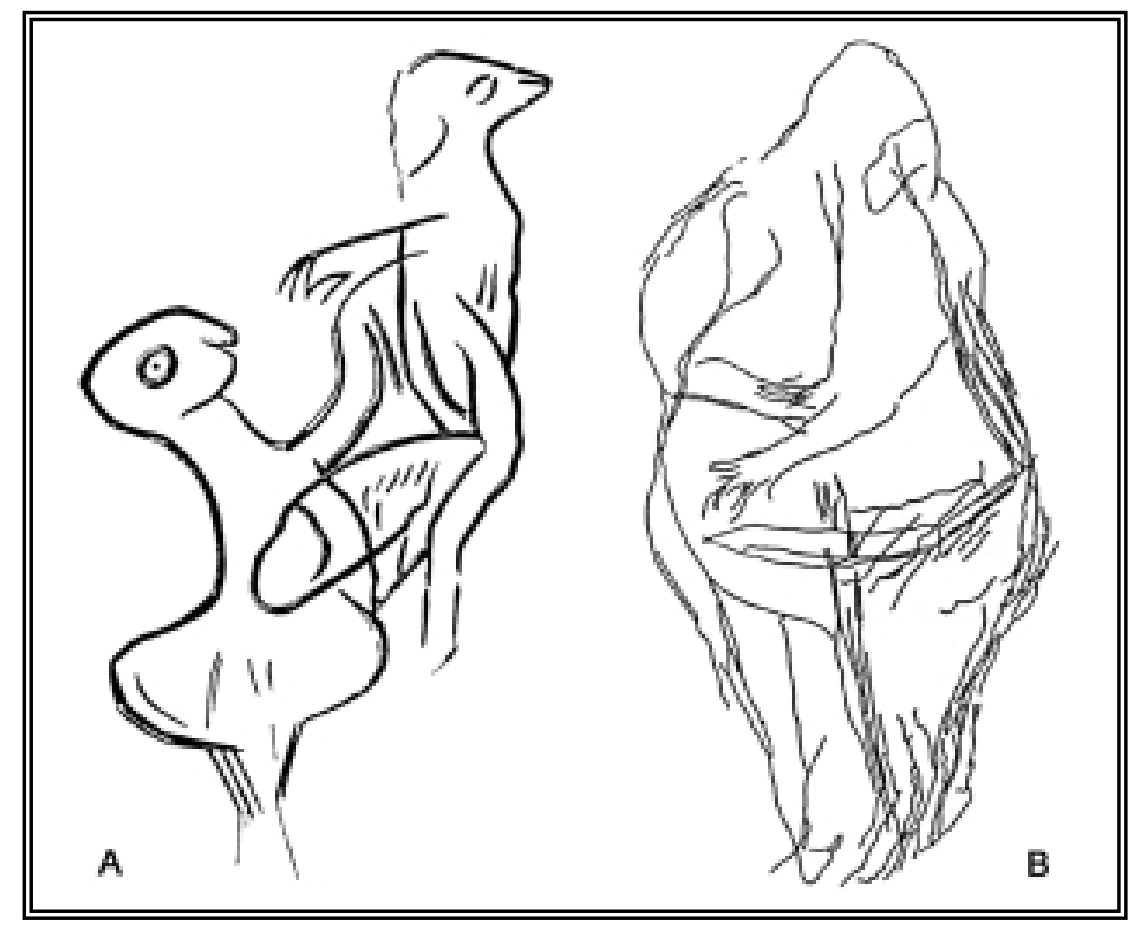

FIGURA 8. Escenas de coito frontal de Los Casares (A) y La Marche (B) (calcos J. Cabré y L. Pales). 
Frente a estas representaciones realistas de cópula es posible que los grupos paleolíticos hayan querido también ejemplificarla de un modo simbólico. La asociación región pubiana/vulva y pene pudiera señalar, más allá de lo femenino y masculino, el coito. Ésta se documenta no sólo en momentos magdalenienses sino también en las primeras fases del Paleolítico superior. El ejemplo más significativo de esos primeros momentos se encuentra en Laussel ${ }^{24}$, donde el mencionado fragmento de glande de pene esculpido presenta en una de sus caras una forma de vulva. También se ha señalado cómo en LaugerieHaute $^{25}$ la existencia de bloques grabados, uno con forma de vulva y otro con forma de pene, pudiera hacer referencia implícita al coito. Para fases magdalenienses se pueden recordar las ya citadas cuevas de Bédeilhac, Fronsac o La Madeleine, entre otras. En todas ellas aparecen referencias gráficas de lo masculino y de lo femenino.

Tampoco debieran dejarse de lado las asociaciones entre signos masculinos y femeninos propuestos por Leroi-Gourhan que compondrían los signos en pareja ${ }^{12}$. Esta valoración, que a todas luces puede parecer demasiado atrevida, sólo encontraría justificación si se aceptara un valor simbólico más allá del aspecto puramente formal de los motivos representados.

\section{Gestos y soportes masturbatorios}

La masturbación es una forma de vivir la sexualidad. A pesar de que algunos sectores sociales ven en esta práctica actitudes desviadas, en cierto modo reprochable, supone un complemento indiscutible de la vida sexual. De hecho las prácticas automasturbatorias no sólo son propias de la pubertad, sino que incluso son un acto inherente en la vida sexual de algunas parejas. Estimulación, excitación y orgasmo van íntimamente ligados a esta práctica. Los grupos paleolíticos han dejado algunas referencias sobre ello que se discuten a continuación.

En un nivel de finales del Magdaleniense de la cueva de Enlène ${ }^{26}$ se recuperó una placa de arenisca que contiene dos representaciones humanas. A pesar de las diferentes lecturas del documento, en lo básico el soporte contiene una representación masculina de la que destaca un sexo de exageradas dimensiones; a éste, y por debajo, se asocian dos líneas en disposición vertical que pudieran estar representado, acorde con el carácter erecto del miembro viril, los diferentes impulsos de la eyaculación. Frente a esta figura, en la que la cabeza no aparece probablemente por una fractura del soporte, se sitúa otra más incompleta de la que se ha discutido el posible carácter femenino a pesar de no haber criterios para poder certificarlo. De ella destaca una mano larga y de palma ancha situada en la zona del vientre y justo por encima del sexo de la anterior figura. La composición presenta un marcado carácter erótico. A pesar de que algunos investigadores han interpretado la composición como propia de un momento de pre o post-coito, desde nuestro punto de vista considerados probable una valoración más explícita: la erección y eyaculación de la figura masculina de sexo hipertrófico y la situación de la mano del otro personaje respecto al anterior pudieran estar ejemplificando una práctica sexual de masturbación masculina.

A pesar de no reconocerse gráficamente la práctica masturbatoria, la expresión del hombre magdaleniense de la roca 2 de Ribeira de Piscos ${ }^{27}$ hace referencia explícita a la eyaculación. Muestra un largo y ancho pene del que se diferencia el glande, que como ya se ha mencionado parece ausente de prepucio (Fig. 9). De este surge una línea que representaría la eyaculación y expulsión del semen. El placer que pudiera suponer esta acción queda reincidido en la figura por el carácter marcadamente abierto de la boca, y en el mismo sentido pudieran interpretarse las líneas curvas y sinuosas que surgen de la cabeza del hombre. La ausencia de otro tipo de representaciones humanas en esta roca lleva a pensar que el gozo pudiera haber sido consecuencia de una práctica individual de onanismo.

También se ha querido ver una actitud masturbatoria en el citado Príapo de Laussel ${ }^{17}$, adscrito a una fase gravetiense (Fig. 3). Como ya se comentó se trata de un bloque calcáreo tallado a modo de escultura masculina con sexo descomunal. Más allá de su exagerado carácter fálico, se ha querido interpretar la posición flexionada y dirigida hacia el pene de la extremidad superior izquierda como representativa del carácter mas- 


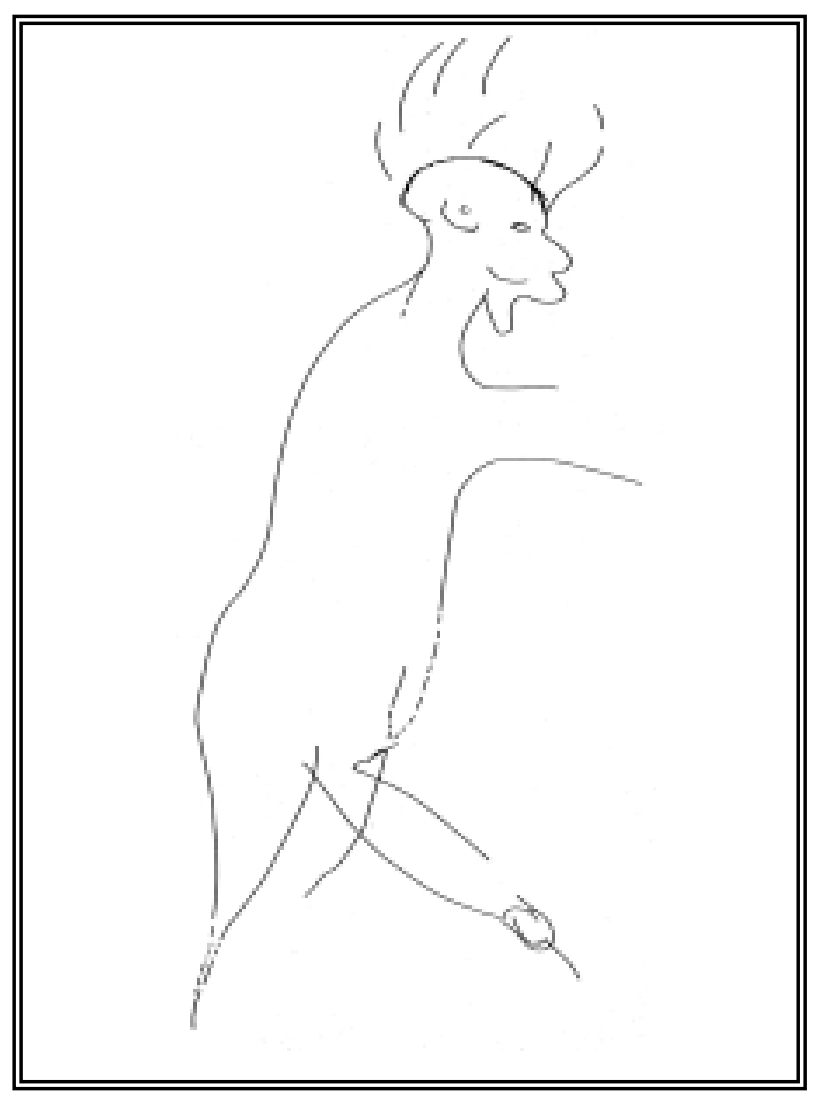

FIGURA 9. Antropomorfo en actitud eyaculatoria de Ribeira de Piscos (calco CNART).

turbatorio. Ahora bien, la posición de la mano de manera alguna es explícita, por lo que se considera improbable el reconocimiento de la masturbación en esta imagen.

Por último algunos investigadores han venido atribuyendo a algunos objetos una interpretación estrechamente ligada a prácticas sexuales masturbatorias. Además de la mano u otras posibles partes del cuerpo, la creación y uso de instrumentos artificiales para el onanismo ha sido frecuente a lo largo de la Historia. Los denominados bastones de mando se consideran piezas excepcionales de arte mueble por su singularidad. La interpretación funcional que se hace de ellos es diversa ${ }^{28}$ : desde pasadores para sujetar las cuerdas de tiendas de campaña hasta cetros que simbolizan poder y distinción social, pasando por objetos de culto totémico, varillas mágicas, enderezadores de puntas óseas, etc. Pero por lo que aquí interesa, algunos autores han incidido en su forma fálica y su potencial ergonomía como consoladores. De ningún modo todos los bastones de mando pueden ser interpretados exclusivamente como soportes para la masturbación femenina o para la práctica de sexo anal pero, por el contrario, se debe aceptar que la forma de alguno de ellos permitiría su uso en este tipo de prácticas sexuales.

\section{El bestialismo}

La obtención de gozo sexual con animales es una práctica poco frecuente. Detrás de esta actitud se esconden numerosos mitos y tabúes. No conocemos con exactitud cuánto de extendida está en nuestra sociedad, pero a buen seguro que no se debe descartar, del mismo modo que tampoco parece probable asegurar que sea un comportamiento extendido.

En el corpus paleolítico sólo contamos con una imagen en Penascosa ${ }^{27}$, donde se asocian un caprino y un hombre esquematizado que presenta una larga verga y el saco escrotal (Fig. 10). La estrecha vinculación espacial de ambos personajes lleva a considerar una clara composición de bestialismo. El problema de esta escena reside en la contemporaneidad de las figuras. Si a todas luces la figura animal es innegablemente paleolítica, no puede asegurarse lo mismo de la humana. El canon de esta última encajaría con el de otros de momentos posteriores. De ser así se trataría de una composición no propiamente paleolítica, sino post-paleolítica, donde el artista que grabó el hombre aprovechó la imagen de caprino grabada al menos unos 6.000-7.000 años antes.

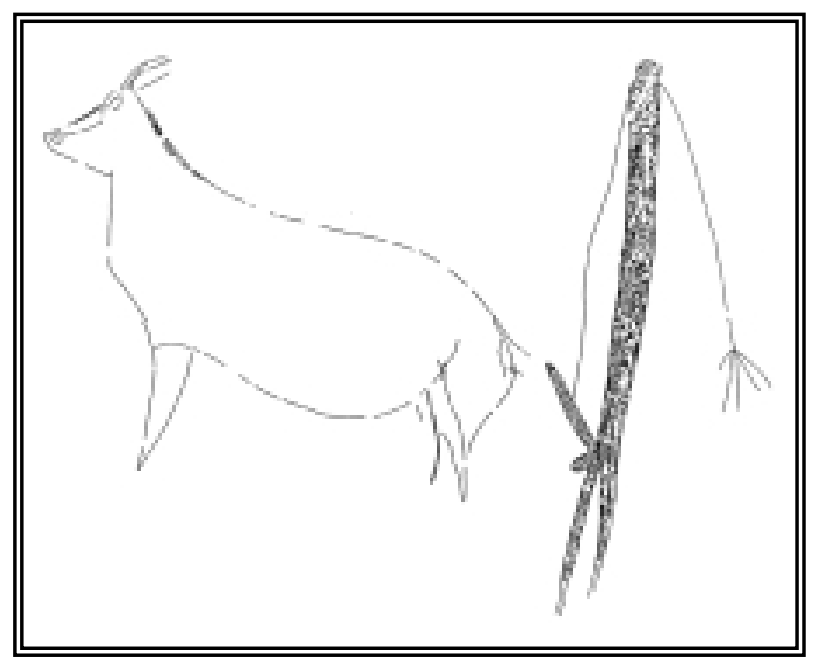

FIGURA 10. Escena de bestialismo de Penascosa (calco CNART). 
Otras situaciones de naturaleza sexual

En algunas imágenes del Paleolítico superior se reconocen elementos de naturaleza sexual difíciles de interpretar. Por más que se busquen referentes etnográficos o se parta de experiencias propias como individuos o como grupo social no es posible dar una valoración a todas las composiciones.

Una de estas situaciones difíciles de valorar se encuentra en la placa 60 del yacimiento francés de La Marche (Fig. 11). En ella algunos autores han visto una composición con carácter dramático donde el rol sexual pudiera tener un valor significativo ${ }^{20}$. Centrándonos en el aspecto sexual destaca el personaje situado a la izquierda, de cara tremendamente naturalista y de pié, que presenta un pene largo probablemente sin prepucio del que destaca el glande y los bordes del meato. A esta figura de brazos levantados y boca

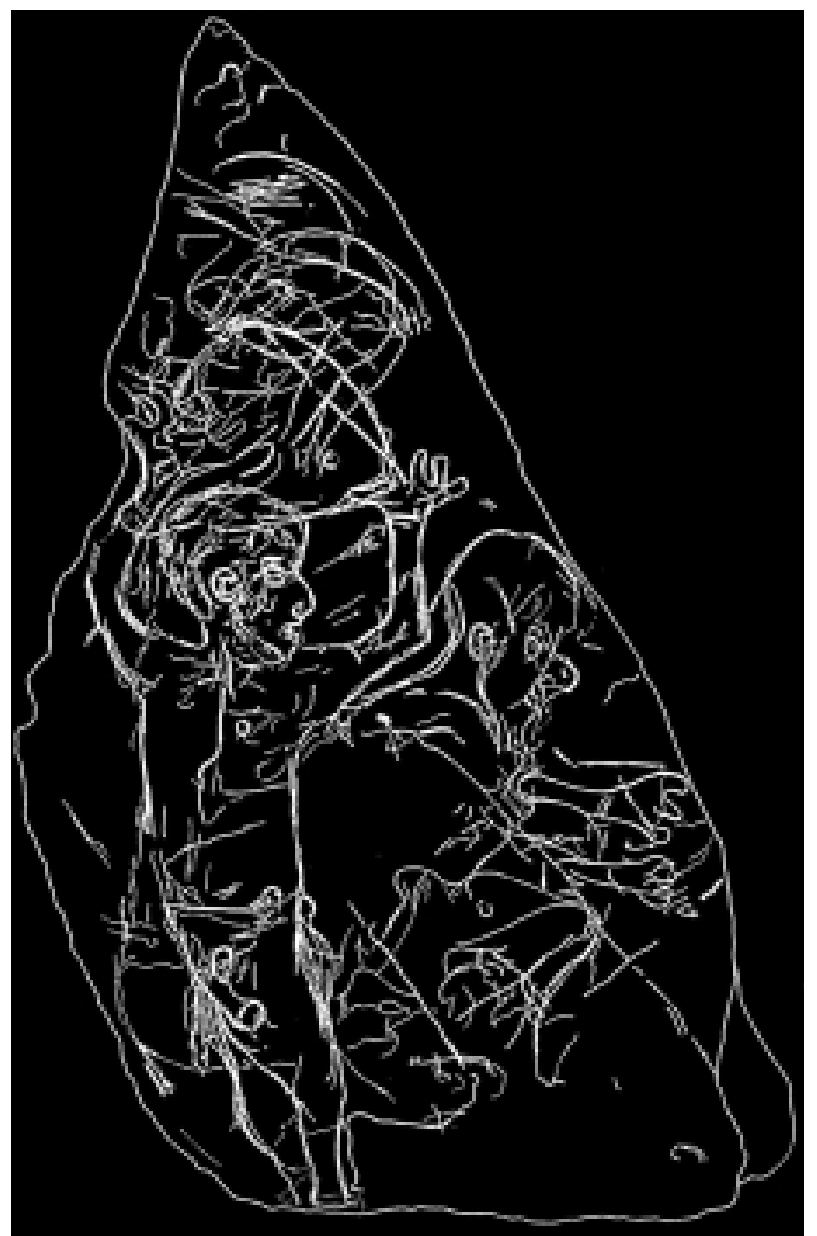

FIGURA 11. Composición sexual de significado incierto de La Marche (calco L. Pales). y manos abiertas, se asocia otra que está semiarrodillada y con los brazos estirados hacia delante y las manos abiertas. Incluso se ha reconocido recientemente una representación femenina parcial con pechos abultados y acéfala en la parte superior que probablemente esté, considerando la morfología de los pechos y la relación tronco y extremidades inferiores, a cuatro patas. Se desconoce por completo la interpretación que debe atribuirse a esta escena.

También de singular y compleja se puede caracterizar la composición del yacimiento italiano de la Grotta dell Addaura $^{29}$ (Fig. 12). En las paredes de la cueva además de bóvidos y caballos grabados hay dieciséis figuras humanas, varias de ellas de carácter eminentemente masculino por la presencia del sexo. Pero lo que destaca es una composición formada por dos figuras masculinas con la verga erecta y marcadamente puntiaguda que se encuentran aparentemente apoyadas sobre un suelo ficticio en una posición forzada. En torno a ellas y en posición envolvente se

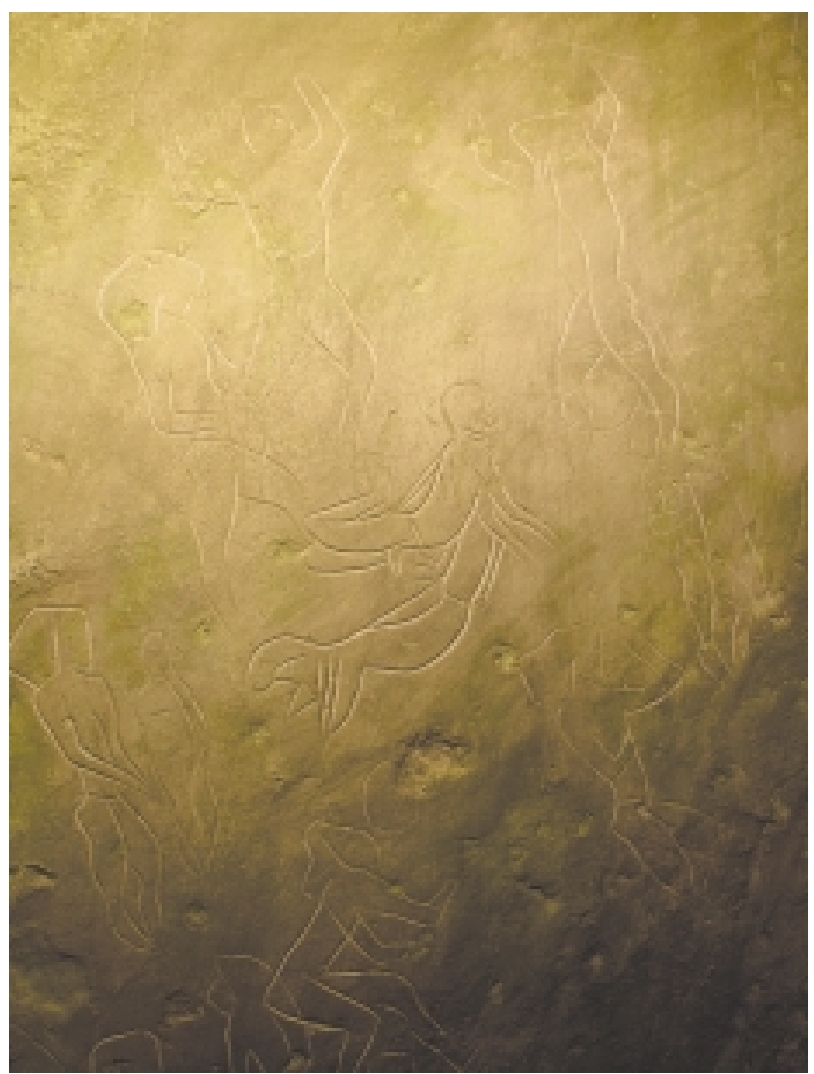

FIGURA 12. Escena de indole sexual de la Grotta d'Addaura. 
grabaron nueve figuras humanas de las que en al menos siete se reconoce un pene flácido y en algunas el escroto; dos de ellas, las situadas en la parte superior de la composición, alzan ambos brazos y otras solamente el izquierdo. La relación escénica entre las figuras parece evidente tanto por su agrupación como por sus similitudes formales y de postura. Mientras la mayor parte de los investigadores aceptan la composición, la interpretación del conjunto no ha sido unívoca. Unos la han definido como una escena acrobática, de exhibición gimnástica. Otros la han explicado indicando que se trata de dos grupos rivales. Algunos creen ver una ceremonia de iniciación donde la virilidad era el componente principal y probablemente los personajes a iniciarse serían unos jóvenes representados por las dos figuras centrales en posición diferente del resto. Otros han visto en ella un carácter dramático, explicándola como una escena de sacrificio humano o de ejecución por estrangulamiento, donde los personajes centrales serían los prisioneros y los envolventes estarian bailando una danza. En conclusión, interpretaciones no faltan, pero lo que sí parece evidente es que lo sexual debe jugar un papel importante en esta escena.

Si hasta ahora se han referido comportamientos basados en la relación entre humanos, también existen composiciones en las que se vincula lo masculino sexuado y lo animal ${ }^{15}$. La relación entre hombre erecto y animal no es numerosa, pero está bien documentada en varios ejemplos como la escena del pozo de Lascaux, donde un hombre con el falo en erección está frente a un bisonte con los intestinos colgando y con una lanza clavada (Fig. 13), el itifálico de Mas d`Azil, donde un hombre erecto parece estar frente a un animal que se ha interpretado como oso pero del que ciertamente sólo se conserva una supuesta pata, y el cazador de Laugerie-Basse, que dirige su arma hacia un bóvido. La relación hombre erecto-animal-arma, claramente patente en dos de los tres casos mencionados, podría simbolizar poder sobre el animal, es decir, virilidad como símbolo de fuerza.

\section{CONCLUSIONES}

El sexo es una constante a lo largo de la Historia de la Humanidad. Las imágenes paleolíticas

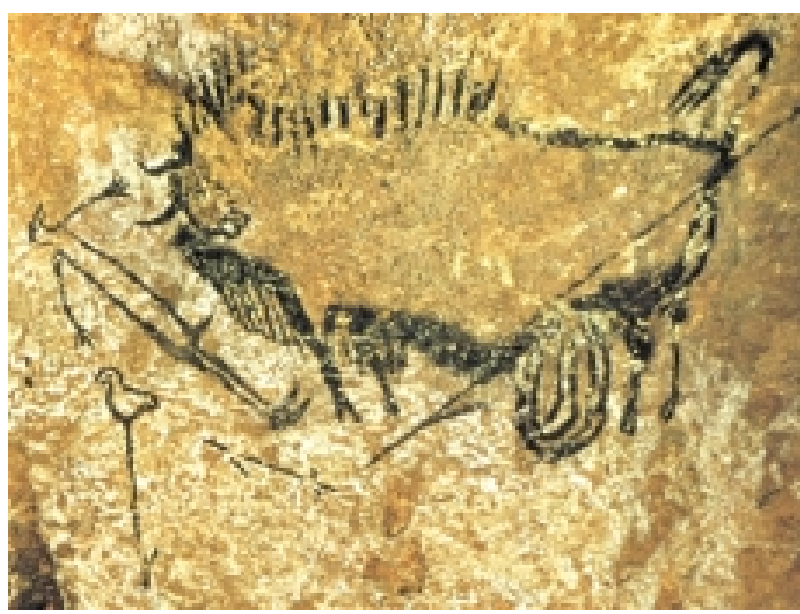

FIGURA 13. Escena del Pozo de Lascaux (foto P. Vidal).

de personajes masculinos con carácter fálico no son numerosas. Esta escueta representación está vinculada a la escasa presencia de la figura humana en el corpus artístico del Paleolítico superior. Se han propuesto diferentes explicaciones, pero es muy probable que la respuesta esté en la consideración zoocéntrica de las sociedades superopaleolíticas, con escasas alusiones a lo antropomórfico. De hecho, al igual que ocurre en otras culturas, la representación humana pudiera estar condicionada por aspectos religiosos o culturales.

La mayor parte de las imágenes masculinas itifálicas recogidas en el imaginario paleolítico son de época magdaleniense. No obstante el contexto estratigráfico que presentan los documentos de arte mobiliar, permite asegurar que algunas imágenes son muchos más antiguas: como los penes de Laugerie-Haute, Laussel, Sergeac y el príapo de Laussel. Se desconoce la datación de la composición coital de Los Casares, aunque para algunos autores podría corresponder también a una fase inicial del Magdaleniense. A partir del Magdaleniense (16.000-10.000 años a.C.) los documentos artísticos muestran imágenes, con carácter expresivo e incluso narrativo, de sexo como reproducción, placer y probablemente juego. Constituyen sin duda muestras que reflejan una vida sexual variada. Amor sensual y apetito sexual son dos tendencias innatas en el género humano. Podría decirse que sus prácticas sexuales fueron, al menos desde esa época, similares a las de nuestra sociedad. 
A partir de una lectura diacrónica de la información disponible, y considerando las imágenes femeninas, se podría señalar que a lo largo de los aproximadamente 30.000 años que dura el Paleolítico superior se produjeron cambios en el comportamiento sexual, o cuanto menos en la "exposición gráfica" que las gentes hicieron de él. Se pasó de unas primeras imágenes donde el carácter relacionado con la reproducción era casi único a otras donde se expresa una visión más actual de la relación sexual y de lo sexual, basada no sólo en lo reproductivo sino también en el gozo y el placer y en la exploración de lo sexual.

\section{REFERENCIAS}

1. Vialou D. Sexualité et art préhistoriques. En Sacco F, Sauvet G, directores. Le prope de 1`homme. Phychanalyse et Préhistoire. Paris, Delachaux et Niestlé. 1988, pp 151171.

2. Taylor T. The Prehistory of Sex. Four Million Years of Human Sexual Culture. London: Fourth Estate, 1996.

3. Angulo J. Sexualidad y reproducción en época glaciar a partir de las observaciones procedentes del arte paleolitico. Revista de Urología 2003; 4-3:133-146.

4. Angulo J, García Díez M. Sexo en Piedra. Sexualidad, reproducción y erotismo en época paleolítica. Madrid: Luzan 5, 2005.

5. Tattersall I. Hacia el ser humano. La singularidad del hombre y la evolución. Barcelona: Península, 1999.

6. Bertranpettit J, Junyent C. Viaje a los orígenes. Barcelona: Crítica, 2001.

7. Cela CJ, Ayala FJ. Senderos de la evolución humana. Madrid: Alianza Editorial, 2001.

8. Djindjian F, Koslowski J, Otte M. Le Paléolithique Supérieur en Europe. Paris: Armand Colin, 1999.

9. Gamble C. Las sociedades paleolíticas de Europa. Barcelona: Ariel, 2001.

10. Garanger J, editor. La Prehistoria en el Mundo. Madrid: Akal, 2002.

11. Bahn P, Vertut J. Images of the ice age. New York: Facts on File, 1988.

12. Leroi-Gourhan A, Delluc B, Delluc G. Préhistoire de 1'art occidental. Paris: Citadelles \& Mazenod, 1995.

13. Lorblanchet M. Les grottes ornées de la préhistoire. Paris: Errance, 1997.

14. Sanchidrián JL. Manual de arte prehistórico. Barcelona: Ariel, 2001.
15. Duhard JP. Réalisme de l’image masculine paléolithique. Grenoble: Jérôme Million, 1996.

16. Cohen C. L'homme des origines. Paris: Seuil, 1999.

17. Duhard JP. Les humains ithyphalliques dans l'art mobilier paléolithique français. Bulletin de la Société Préhistorique Française 1992;89-6:172-183.

18. Barandiarán I. Grupos homoespecíficos en el imaginario mobiliar magdaleniense. Retratos de familia y cuadros de género. Vitoria: Servicio Editorial Universidad del País Vasco, 2003.

19. Barrière C. L’art pariétal des grottes des Combarelles. Angoulême: Paléo-Hors série, 1997.

20. Pales L. Les gravures de la Marche. II-Les humains. Ophrys, 1976.

21. Marquesa X. Kamasutra español. Las mejores técnicas, posturas y juegos para hacer el amor. Barcelona: Sex, 2002.

22. Cabré J. Investigaciones en las cuevas de Los Casares y de la Hoz (1934-1941). Madrid: Rayuela, 1998.

23. Jordá F. El mamut en el arte paleolítico peninsular y la hierogamia de Los Casares. En Homenaje al Prof. Martín Almagro Basch I. Madrid, Ministerio de Cultura. 1983; 265-272.

24. Duhard JP, Roussot A. Le gland pénien sculpté de Laussel. Bulletin de la Société Préhistorique Française 1988; 852:43-44.

25. Delluc B, Delluc G. L'art pariétal archaïque en Aquitaine. Paris: XXVIII Gallia Préhistorique. Centre National de la Recherche Scientifique, 1991.

26. Bégouën R, Briois F, Clottes J, Servelle C. Art mobilier sur support lithique d’Enlène (Montesquieu-Avantès, Ariège). Collection Bégouën du Musée de 1'Homme. Ars Praehistorica 1985;3-4:25-80.

27. Baptista AM. No tempo sem tempo. A arte dos caçadores paleolíticos do Vale do Côa. Vila Nova de Foz Côa: Parque Arqueológico Vale do Côa, 1999.

28. Giedion S. El presente eterno: los comienzos del arte. Una aportación al tema de la constancia y el cambio. Madrid: Alianza, 1981.

29. Graziosi P. L'arte preistorica in Italia. Florencia: Sansoni, 1973.

Dr. M. García Diez

Dpto. de Geografía, Prehistoria y Arqueología

Universidad del País Vasco

Tomás y Valiente, $\mathrm{s} / \mathrm{n}$

01006 Vitoria

E-mail: marcosgarcia@inicia.es

(Trabajo recibido el 31 de agosto 2005) 